\title{
Coffee beverage reduces ROS production and does not affect the organism's response against Candida albicans
}

\author{
Alessandra dos Santos Danziger Silvério, Rosemary Gualberto Fonseca Alvarenga Pereira1, \\ Stella Maris da Silveira Duarte ${ }^{2}$, Sônia Aparecida Figueiredo², Cláudia de Souza Ferreira², \\ Adriene Ribeiro Lima', Fernanda Borges de Araújo Paula², Tomaz Henrique Araújo3, \\ Eric Batista Ferreira ${ }^{4}$, Maria Rita Rodrigues ${ }^{2 *}$ (1) \\ 'Departamento de Ciências dos Alimentos, Universidade Federal de Lavras, Lavras, Minas Gerais, Brasil \\ ${ }^{2}$ Departamento de Análises Clínicas e Toxicológicas, Faculdade de Ciências Farmacêuticas, Universidade Federal de Alfenas, \\ Alfenas, Minas Gerais, Brasil \\ ${ }^{3}$ Instituto de Ciências Biomédicas, Universidade Federal de Alfenas, Alfenas, Minas Gerais, Brasil \\ ${ }^{4}$ Instituto de Ciências Exatas, Departamento de Matemática, Universidade Federal de Alfenas, Alfenas, Minas Gerais, Brasil \\ *Corresponding author: rodrigues.mrita@gmail.com
}

\begin{abstract}
Coffee is a mixture of substances with potential beneficial and adverse health effects. Several studies demonstrate the antioxidant effect of the phenolics compounds present in coffee. Neutrophils produce reactive oxygen species (ROS) by activating of nicotinamide adenine dinucleotide phosphate (NADPH) oxidase 2 (NOX2), which plays a key role in organism defense against microbial pathogens. Diabetes mellitus patients are more susceptible to bacterial and fungal infections. The present study evaluated the influence of coffee beverage on NOX2 activity and ROS generation and the impact of this effect on phagocytosis and killing of Candida albicans by neutrophils from diabetic and non-diabetic animals. Diabetes mellitus was induced in male Wistar rats using $2 \%$ alloxan. Diabetic and non-diabetic animals were divided into groups treated and untreated with coffee drink $(7.2 \mathrm{~mL} / \mathrm{kg} /$ day) or apocyanine $(16 \mathrm{mg} / \mathrm{kg} /$ day) for 50 days. After 50 days, the animals' glycemic profile was measured by blood glucose and glycated hemoglobin (HbA1c) tests. The generation of ROS in neutrophilic cells was measured by chemiluminescence and cytochrome $C$ reduction assays. $C$. albicans phagocytosis and death were evaluated by optical microscopy using the May-Grunwald-Giemsa staining method. The coffee drink has not altered the glycemic profile and NOX2 activity of the animals. However, coffee reduced the ROS pool in non-diabetic and diabetic animals, but this activity did not harm the phagocytosis or killing of neutrophils. Treatment with apocyanin decreased ROS production and killing capacity of neutrophils from non-diabetic animals against $C$. albicans. We suggest that the coffee drink intake prevents oxidative damage and does not impair response of the organism against opportunistic microorganism.
\end{abstract}

Keywords: Candida albicans. Coffea arabica L. Diabetes mellitus. NOX2. Reactive oxygen species.

\section{How to cite}

Silvério ASD, Pereira RGF, Duarte SMS, Figueiredo SA, Ferreira CS, Lima AR, Paula FBA, Araújo TH, Ferreira EB, Rodrigues MR. Coffee beverage reduces ROS production and does not affect the organism's response against Candida albicans. Rev Ciênc Farm Básica Apl. 2020;41:e684. https://doi.org/10.4322/2179-443X.0684

Financial support: None.

Conflicts of interest: The authors have no conflict of interest to declare.

Received on August 10, 2020. Accepted on November 3, 2020. 


\section{INTRODUTION}

Coffee consumption is widespread in many countries and reached 162.12 million bags consumed in 2017/18 (Jeszka-Skowron et al., 2020). Its potential health effects have been widely studied, such as reduced risk of disease (type 2 diabetes mellitus, depression, cancer, hepatic injury, cardiovascular disorders, among others), regulation of blood glucose levels, beneficial action on the gastrointestinal tract and intestinal microbiota, increased mental alertness, high antioxidant activity (Costabile et al., 2018; Melo Pereira et al., 2020; Muñoz et al., 2020). The relationship between the consumption of coffee and human health and disease are complex as its composition, its preparation and the ingested dose may vary. Among the many bioactive substances that are present in the drink, two stand out: caffeine and chlorogenic acid, which are substances associated with reduced risk of developing several diseases such as arteriosclerosis, cancer and diabetes mellitus (Ludwig et al., 2014a; Muñoz et al., 2020; Reis, et al. 2019).

Diabetes mellitus is characterized by chronic hyperglycemia and metabolic changes in lipids, carbohydrates and proteins due to defects in secretion and insulin resistance or both or downgrade of insulin levels (Association, 2016; Mirza et al., 2019). A high glucose level is considered an important factor in the development of tissue damage. Some authors suggest that these damages are caused by hyperglycemia linked to increased flow through the polyol pathway, by activation of protein kinase C (PKC) isoforms and hexosamine biosynthetic pathway with increased formation of advanced glycation end products (AGEs) (Souza Ferreira et al., 2016; Ding, et al. 2019; Jud and Sourij, 2019; Shakeel, 2015). All of these mechanisms may result in an overproduction of reactive oxygen species (ROS) in mitochondria (Ding et al., 2019).

The ROS generation seems to be a common thread among these pathways, and a major source of ROS is the activation of nicotinamide adenine dinucleotide phosphate (NADPH) oxidase 2 (NOX2) (de Souza Ferreira et al., 2016; Shah \& Brownlee, 2016). The glucose level stimulates phagocyte-type NADPH oxidase activity that influences the functioning of pancreatic beta cells (Ding et al., 2019). The killing and microbicidal functions of neutrophils are directly related to the metabolic pathway that involves NOX2 and PKC and generates ROS, mainly superoxide radicals. Changes in ROS production by phagocytes have been identified as a major cause of immune system dysfunction in diabetics and of their increased susceptibility to bacterial and fungal infections (Souza Ferreira et al., 2016; Kempf et al., 2007).

Evidences suggest that high consumption of coffee may reduce the risk of diabetes mellitus by affecting glucose metabolism with respect to insulin tolerance and oxidative stress as a consequence of chronic hyperglycemia (Costabile et al., 2018; Mellbye et al., 2015). Despite numerous reports in the literature on the association between coffee consumption and diabetes mellitus, these data are still inconclusive (Melo Pereira et al., 2020; Kalschne et al., 2019; Lee et al., 2015; Stefanello et al., 2019). In this context, the present study aimed to verify the influence of coffee beverage on ROS generation by NOX2 and on the phagocytic function of neutrophils and microbicidal activity toward C. albicans in diabetic rats.

\section{MATERIAL AND METHODS}

\section{The preparation, characterization and determining bioactive compounds of integral coffee beverage}

Samples of Brazilian coffee (Coffea arabica L.) were provided from Fazenda Conquista (865 $m$ altitude), belonging to Ipanema Agricola S.A., located in Alfenas, MG. Coffee beverage was prepared at a $10 \%(\mathrm{w} / \mathrm{v})$ concentration and then was lyophilized to facilitate the characterization of the sample (Lima et al., 2010). The lyophilized powder was stored in a freezer $\left(-20^{\circ} \mathrm{C}\right)$ and was only solubilized at the time of administration to the animals. This procedure ensured the reproducibility of the study and enabled the administration of equal amounts of soluble solids to the rats. 
The characterization of the coffee drink was carried out by determining the total phenolic content and bioactive compounds. The levels of total phenolics present in the sample was measured using the Folin-Ciocalteu method, with galic acid as the reference standard. To determine the bioactive constituents such as caffeine, chlorogenic acid (CGA) and total phenol, hot water extraction procedures were used according to (Lima et al., 2010). The chromatographic separation of these compounds was performed using a High Performance Liquid Chromatography (HPLC) equipped with a data transmitter, with a high pressure pump (Code number PU-4086, Jasco LC- NetII/ADC, Japan), a refrigerated automatic injector and a photodiode detector (Code number 6832-J002B, Model MD-2015, Jasco AS-2057 Plus, Japan).

HPLC device used a Phenomenex C18 ODS (octadecysilyl) reverse phase column ( $250 \times 4.60$ $\mathrm{mm} ; 2.5 \mu \mathrm{m}$ ), with a gradient elution process, whose flow rate was $1 \mathrm{~mL} / \mathrm{min}$ for 30 minutes at temperature environment. The gradient technique employed (A) acetate buffer and (B) methanol (Code number 34860-1L-R, PA, Aldrich, Germany) (HPLC grade). The concentrations of 5-caffeoylquinic acid (5-CQA) (Code number SMB00131-1MG) and caffeine (Code number C1778-1VL) were calculated using calibration curves made with their respective standards (Sigma Chemical Co, St. Louis-USA).

\section{Induction of Diabetes mellitus}

After 12 hours fasting, diabetes mellitus induction was performed in male Wistar rats by intraperitoneal administration of $2 \%$ alloxan $(150 \mathrm{mg} / \mathrm{kg}$ ) (Szkudelski, 2001). Alloxan was the compound of choice for cost reasons (cheaper than streptozotocin) and because it is the standardized protocol in the laboratory, in addition to being widely used in the induction of experimental diabetes mellitus (Anyanwu et al., 2019; Bacevic et al., 2020; Chunudom et al., 2020; Singh et al., 2020). In this study, animals with blood glucose levels $\geq 250 \mathrm{mg} / \mathrm{dL}$ were considered diabetic (7 days after induction) and included in the experiment. Blood glucose measurements were monitored weekly using the blood collection from the rats' tails to monitor the diabetic condition.

\section{Experimental delineation}

All in vivo experiments were performed in accordance with the guidelines of the International Council for Laboratory Animal Science (ICLAS) and were approved by the Ethical Committee for Animal Experimentation of Federal University of Alfenal (Unifal-MG) (document $n^{\circ}$. 420/2012) before the study was carried out. Twelve-week-old male Wistar rats (Rattus norvegicus) weighing $320 \pm 20 \mathrm{~g}$ were obtained from the Unifal-MG vivarium. These animals were maintained in a temperature of $25^{\circ} \mathrm{C}$ under a $12 \mathrm{~h}: 12 \mathrm{~h}$ artificial light/dark cycle and received commercial feed and water ad libitum during the entire experimental period.

After a week of acclimatization, the animals were divided into 6 groups $(n=10 /$ group): nondiabetic animals treated with distilled water (non-diabetic), non-diabetic animals treated with apocynin (non-diabetic + APO), non-diabetic animals treated with arabica coffee drink (nondiabetic + coffee), diabetic animals treated with water (diabetic), diabetic rats treated with apocynin (diabetic + APO), and diabetic animals treated with arabica coffee drink (diabetic + coffee).

The animals were treated with a coffee drink or apocinin, a natural organic antioxidant with the ability to inhibit the activation of nicotinamide adenine dinucleotide phosphate (NADPH) oxidase (NOX) and increase ROS capture (Wang et al., 2019; Xin et al., 2018). The administration of apocynin (Sigma) (16 mg/kg/day) (Nam et al., 2009) or of filtered coffee drink (a dose of $7.2 \mathrm{~mL} / \mathrm{kg} /$ day - equivalent to a daily human consumption of eight cups of $50 \mathrm{~mL}$ of coffee) started 7 days after induction and confirmation of the diabetic status and was performed by gavage for 50 days. The non-diabetic group received the same amount of water. 


\section{Obtaining neutrophils}

After 50 days of treatment, the neutrophil recruitment was performed by intraperitoneal administration of $2 \mathrm{~mL}$ of $12 \%(\mathrm{w} / \mathrm{v}$ ) sodium caseinate (Sigma) diluted in sterile $0.9 \%$ saline. After 4 hours of the procedure, the rats were anesthetized by intraperitoneal injection of 40 $\mathrm{mg} / \mathrm{kg}$ of sodium pentobarbital and the intraperitoneal cavity was washed with $15 \mathrm{~mL}$ of cold sterile phosphate-buffered saline (PBS). The cell suspension was collected by aspiration with syringe ( $40 \times 12 \mathrm{~mm}$ needle) after massage of the abdomen. This suspension was centrifuged at $4^{\circ} \mathrm{C}(500 \mathrm{~g}$ for $10 \mathrm{~min}$ ) and kept on ice until the testing (Souza Ferreira et al., 2016). The experiments were carried out in triplicates.

\section{Cell counting and viability assessment}

The viable cells (> 98\% neutrophils) were quantified using a Neubauer chamber under an optical microscope employing the Trypan blue exclusion test (Souza Ferreira et al., 2016).

\section{Glycemia and HbA1c levels}

The blood sample was obtained by cardiac puncture. Blood glucose levels were determined by the enzymatic method using an automatic analyzer (HumaStar 80-In vitro Diagnostic Ltda) according to the manufacturers. Glycated hemoglobin (HbA1c) was assessed by HPLC using the D-10 Dual BIO-RAD ion exchange equipment (Souza Ferreira et al., 2016). Dosages were performed in triplicates.

\section{NOX2 activity}

The NOX2 activity was determined by the quantification of its superoxide anions produced in neutrophilic cells. The test measured the reduction of cytochrome C. The assay used $2 \times 10^{6}$ neutrophils $/ \mathrm{mL}, 100 \mu \mathrm{mol} / \mathrm{L}$ cytochrome $\mathrm{C}$ and $20 \mathrm{mg} / \mathrm{mL}$ catalase in PBS containing 10 $\mathrm{mmol} / \mathrm{L}$ glucose $(\mathrm{pH} 7.4)$ added to a plastic bucket. Superoxide production was initiated by the addition of PMA (12-myristate 13-acetate phorbol) $(53 \mathrm{ng} / \mathrm{mL})$ and the reaction was monitored by spectrophotometry for 3 min at a wavelength of $550 \mathrm{~nm}$ (Souza Ferreira et al., 2016; Jones \& Hancock, 1994). The tests were performed in triplicates.

\section{Chemiluminescence amplified by Luminol}

Neutrophils were activated by PMA (53 ng per test) and added to a reaction mixture containing $1 \mathrm{mmol} / \mathrm{L}$ of luminol and $1 \times 10^{6}$ neutrophils per milliliter. The chemiluminescence produced was quantified in a Geomax ${ }^{\circledR} \mathrm{TM} 20 / 20$ luminometer, and the results expressed as units of relative light per second (RLU/s). The reaction was performed in PBS ( $\mathrm{pH} 7.4)$ and followed by $30 \mathrm{~min}$ at $37^{\circ} \mathrm{C}$ (Souza Ferreira et al., 2016; Rodrigues et al., 2002). Assays were performed in triplicates.

\section{Yeast preparation}

C. albicans yeast (American Type Culture Collection (ATCC) 5372) was opsonized by $10 \%$ $(\mathrm{v} / \mathrm{v})$ rat autologous serum in $0.01 \mathrm{~mol} / \mathrm{L}$ of phosphate buffer $(\mathrm{pH} 7.2)$, containing $0.15 \mathrm{~mol} / \mathrm{L}$ of sodium chloride $(\mathrm{NaCl})$ in PBS for $30 \mathrm{~min}$ at $37^{\circ} \mathrm{C}$ with orbital shaking at $150 \mathrm{rpm}$. Viability was measured by the $0.05 \%$ methylene blue exclusion test $(99.9 \%)$, and the number of $C$. albicans was quantified in the Neubauer chamber (Souza Ferreira et al., 2012; Souza Ferreira et al., 2016).

\section{Phagocytosis and candidacidal activity}

A number of $1 \times 10^{6}$ neutrophils were incubated at $37^{\circ} \mathrm{C}$ with opsonized C. albicans $\left(1 \times 10^{7}\right)$ at a $1: 10$ ratio at $37^{\circ} \mathrm{C}$ in $1 \mathrm{~mL}$ of RPMI medium in a rotatory system (10 rpm). After $30,60,90$ and 120 min of incubation, an aliquot of $50 \mu \mathrm{L}$ of this suspension were adhered to cover slip 
glass by cytocentrifugation (Sorocito FANEM). After centrifugation, cover slips were stained with Wright's and May-Giemsa stains. Neutrophils with one or more attached yeasts were scored as phagocytic cells. The percentage of phagocytic cells and the number of yeast cells attached per 100 randomly chosen neutrophils were counted (Souza Ferreira et al., 2012). For candidacidal activity determination, cell viability of attached cells was evaluated using the dye exclusion (Rosenfeld) test (Souza et al., 2001). The experiments were performed in triplicates.

\section{Statistical analysis}

The results were expressed as the mean \pm standard deviation (SD). The obtained data were statistically analyzed by one-way analysis of variance (ANOVA) followed by Tukey's test of multiple comparisons and the level of significance was set to $p<0.05$.

\section{RESULTS AND DISCUSSION}

Coffee has in its composition an infinity of chemical substances such as chlorogenic and caffeic acid, lactones, diterpenes, including cafestol and kahweol, niacin, trigonelline, caffeine, among others, all belonging to different classes and, therefore, with relevant pharmacological (Cano-Marquina et al., 2013; Romualdo et al., 2019). The profiles of the bioactive compounds evaluated in this work are shown in Table 1. The detected caffeine content was similar to the average levels found in beverages prepared from Brazilian Arabica beans using the filter method (Camargo et al., 1999; Jeszka-Skowron et al., 2020). Caffeine is thermally stable, unlike trigonelline and CGA, which are thermosensitive, so the processes of roasting, extraction and drying should have less influence on the final content of caffeine in the product (Kwak et al., 2017; Marcucci et al., 2013). However, roasting causes significant losses of trigonelline and, consequently, reduces its antioxidant potential (Kwak et al., 2017). The concentration of this compound in the beverages varies according to the type of coffee (Yoshinari et al., 2013).

Table 1. Determination of caffeine, total phenols and total chlorogenic acids levels present in the integral coffee drink. The results represent the mean \pm standard deviation $(n=5)$.

\begin{tabular}{cc}
\hline Bioactive compounds & Concentration \\
\hline Caffeine $(\mathrm{mg} / \mathrm{dL})$ & $0.724 \pm 0.010$ \\
Total phenol $(\mathrm{mg}$ gallic acid eq/mL) & $6.640 \pm 0.040$ \\
Total CGA $(\mathrm{mg} / \mathrm{mL})$ & $1.335 \pm 0.017$ \\
\hline
\end{tabular}

CGA: chlorogenic acids.

Coffee is a major source of chlorogenic acid in the human diet; daily intake in coffee drinkers is $0.5-1.0 \mathrm{~g}$; coffee abstainers will usually ingest $<100 \mathrm{mg}$ for day. Several in vitro studies have suggested the potential beneficial effects of chlorogenic acid on human health, such as antioxidant, antidiabetic, anticarcinogenic, cardioprotective, antibacterial effects, etc (Ludwig et al., 2014b; López-Froilán et al., 2016; Tomac et al., 2020). The dose used in this study $(7.2 \mathrm{~mL} / \mathrm{kg} /$ day) is equivalent to a daily human consumption of 8 cups of $50 \mathrm{~mL}(400 \mathrm{~mL})$ of boiled and filtered coffee. Thus, the coffee drink administered to the animals contains about $534 \mathrm{mg} /$ day of CGA (Table 1).

To verify the installation of diabetes mellitus, the blood glucose level was determined seven days after the induction of diabetes mellitus and during the treatment of the animals, the glucose level was monitored weekly (values $\geq 250 \mathrm{mg} / \mathrm{dL}$ ). The glucose levels were also quantified at the time of euthanasia, and a significant difference (an increase of 300\%) was observed between the non-diabetic animals and diabetic groups (Figure 1A). Because blood glucose indicates only a momentary state, we evaluated the glycation of proteins by measuring $\mathrm{HbA} 1 \mathrm{c}$. After 50 days of treatment, the $\mathrm{HbA1c}$ levels were significantly higher (an increase of 150\%) in diabetic than non-diabetic animals, and this effect was independent of treatment with APO or coffee (Figure 1B). 
a

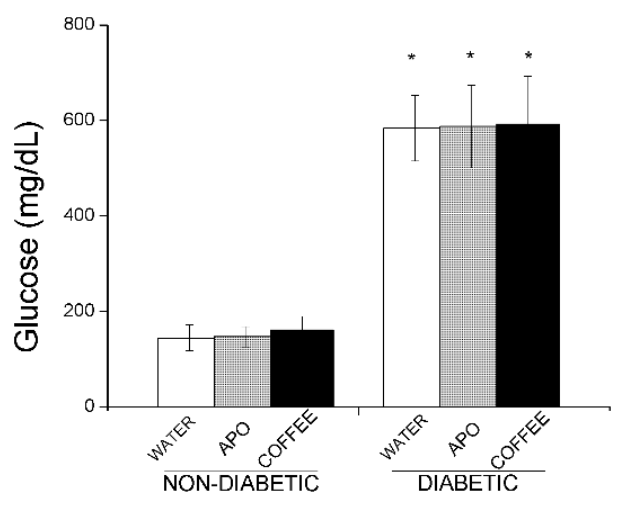

b

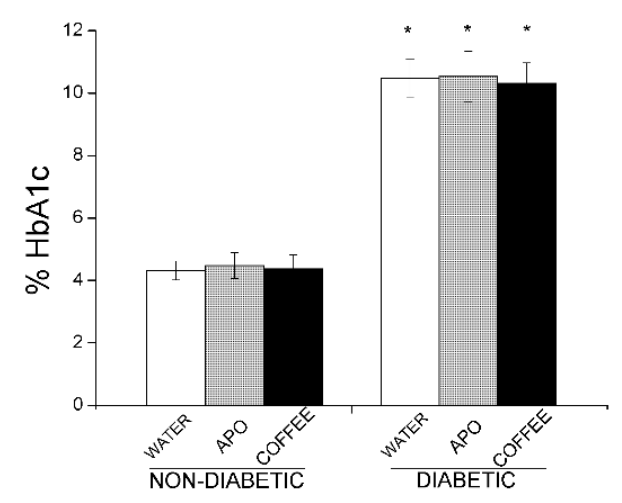

Figure 1. (a) Fasting blood glucose measurement $(\mathrm{mg} / \mathrm{dL})$ in the serum. (b) Blood HbA1c level measurement (\%). Non-diabetics or diabetics corresponded to animals treated with: water, APO or coffee drink. The values are presented as means \pm SD of the three experiments performed in triplicate.

${ }^{*} p<0.001$ statistically significant difference compared diabetic with non-diabetic group (with the respective treatments). There was no statistical difference between treatments within each group, according to a one-way ANOVA followed by the Tukey test $(p<0.05)$. APO: apocynin.

The data regarding the influence of coffee on glycaemia in diabetic subjects are contradictory. Studies demonstrated a hyperglycemic acute effect, a decrease in insulin sensitivity and glucose tolerance, all related to caffeine action, but this effect can be modified when caffeine is consumed in a complex mixture, such as coffee. This is because other compounds of coffee can neutralize or antagonize the negative effect of caffeine on glucose metabolism, e.g., chlorogenic acid and trigonelline that have a hypoglycemic effect and responses to insulin (Di Girolamo et al., 2016; Jeszka-Skowron et al., 2020). Long-term caffeine intake promotes an increase in the secretion of the hormone adiponectin with insulin sensitizing properties. Coffee also stimulates the release of glucagon-like peptide 1 (GLP-1) and thus contributes to postprandial insulin secretion (Di Girolamo et al., 2016).

Components such as chlorogenic acid, melanoidins, quinides and $\mathrm{N}$-methylpyridinium (PMN) can clearly affect glucose and insulin metabolism (Di Girolamo et al., 2016). An in vitro study demonstrated that cafestol stimulates insulin secretion and increases glucose uptake in muscle cells (Mellbye et al., 2015). In vitro tests also demonstrate that chlorogenic acid inhibits hepatic enzyme glucose-6-phosphatase which plays a critical role in glucose production in the liver (Van Dijk et al., 2009). A light roasting of the coffee beans provides a high concentration of CGA and trigonelline, which contribute to greater insulin sensitivity and secretion and better glucose uptake. While a more intense roasting process reduces the content of these components, changes their antioxidant activity and impacts on physiological effects (Di Girolamo et al., 2016).

Studies on the effect of apocynin and the NOX2 system on glycaemia are scarce and focus on the complications of hyperglycemia. Here, treatment of the animals with apocynin did not affect glucose and HBA1c levels (Figure 1), and this result is consistent with the descriptions of this effect in the literature (Thallas-Bonke et al., 2008). We evaluated the production of superoxide anion, which reflects the activity of NOX2 through the reduction of cytochrome $C$. Figure $2 \mathrm{~A}$ shows no difference in the generation of superoxide anion among non-diabetic and diabetic animals. (Inoguchi et al., 1992) demonstrated that the production of ROS in cultured endothelial cells exposed to high glucose levels is similar to that of cells in response to stimulation by PMA, suggesting a greater translocation of PKC to the membrane and, thereby, providing an increased sensitivity to stimulation by PKC in neutrophils of diabetic patients. In this study, PMA was added to both the diabetic and non-diabetic groups. 


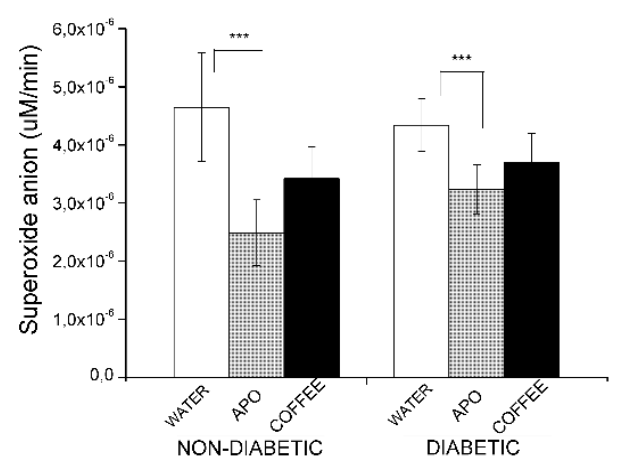

b

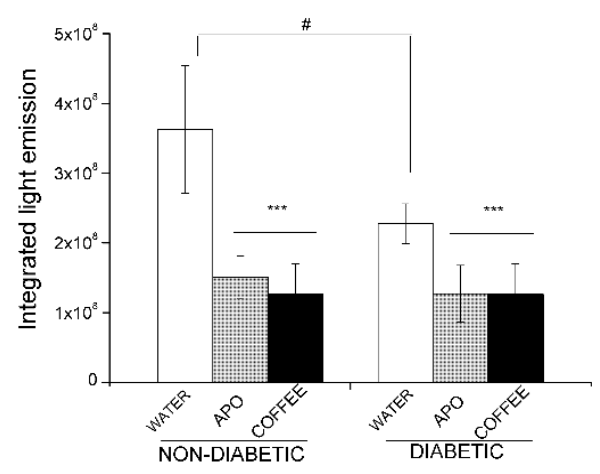

Figure 2. Measurement of reactive oxygen species (ROS). (a) Superoxide anions on the peritoneal neutrophils $\left(1 \times 10^{6}\right.$ cells $)$ of rats stimulated with PMA $\left(53 \mathrm{ng} \cdot \mathrm{mL}^{-1}\right) . * \star \star p<0.001$ means that there was a statistical difference. (b) Measurement of the pool of ROS obtained for the oxidation of luminol promoted by peritoneal neutrophils $\left(1 \times 10^{6}\right.$ cells). ${ }^{\#} p<0.001$ statistically significant difference compared diabetic with non-diabetic group. ${ }^{* * *} p<0.001$ means that there was no statistical difference. Nondiabetics or diabetics corresponded to animals treated with: water, APO or coffee drink. The values are presented as means \pm SD of the three experiments performed in triplicate. PMA: 12-myristate 13acetate phorbol, APO: apocynin.

Apocynin, as expected, significantly inhibited the production of superoxide anion in both groups and, consequently, reduced oxidative stress (Wang et al., 2019), but the inhibitory effect was more pronounced in the non-diabetic group. Apocinin is a potent NOX inhibitor that acts by inhibiting the translocation of $\mathrm{p} 47$ phox to the cell membrane and prevents system assembly, and has been widely used as a non-toxic NOX2 inhibitor (Qiu et al., 2016). NOX2 inhibition can preserve pancreatic islets due to reduced ROS production and thereby regulate insulin secretion (Ding et al., 2019). The apocynin inhibition mechanism starts with its activation by hydrogen peroxide $\left(\mathrm{H}_{2} \mathrm{O}_{2}\right)$ and myeloperoxidase (MPO) to form the diapocinin dimer, which oxidizes the NOX2 thiols and blocks the translocation of p47phox to the membranes and consequently the assembly of this enzyme (Pintard et al., 2020). Some studies have shown that the apocynin dimer is more efficient than apocynin itself (Almeida et al., 2012) and others suggest that only the dimer is able to block the activity of NOX2 (Van den Worm et al., 2001). Our group previously demonstrated that diabetic animals have lower MPO activity than non-diabetic animals (Souza Ferreira et al., 2012) which could explain the less pronounced effect of apocynin in the diabetic group.

The coffee did not affect the production of superoxide anion, independent of the diabetic state (Figure 2A). The superoxide anion originates from other species, e.g., $\mathrm{H}_{2} \mathrm{O}_{2}$, hydroxyl radical $\left(\mathrm{OH}^{\circ}\right)$, hypochlorous acid $(\mathrm{HOCl})$ and nitric oxide (NO) (Pintard et al., 2020). We also assessed the extracellular ROS production by chemiluminescence amplified by luminol. As observed in Figure 2B, the hyperglycemia decreased the pool of ROS in neutrophils. The myeloperoxidase catalyzes the reaction involving reactive species, such as hydrogen peroxide and chloride ion, generating $\mathrm{HOCl}$. These species are involved in microbial killing (Galijasevic, 2019; Winterbourn and Kettle, 2013). When evaluating the ROS pool, our measurements include $\mathrm{HOCl}$ produced by MPO-dependent activity. We reported that neutrophil MPO activity is decreased in diabetic rats (Souza Ferreira et al., 2012). The reduced production of ROS observed in Figure 2 may reflect this decrease of $\mathrm{HOCl}$, because of the low activity of MPO (Figure 2B).

Apocynin and coffee both inhibited neutrophil ROS production. The inhibitory effect of apocynin on ROS generation can be is well described. As for coffee, the studies are often in conflict. Numerous studies describe the antioxidant properties of coffee, while others show the opposite effect (AIAmri et al., 2020; Chu et al., 2011; Kwak et al., 2017; Tomac et al., 2020; 
Wu et al., 2011). One of the most widely studied and proven properties of coffee is its antioxidant activity related to natural phenolic compounds such as chlorogenic acid, caffeine and melanoidins, which contributes to the improvement of the pathophysiological characteristics of type 2 diabetes mellitus (T2D) (Butt \& Sultan, 2011; Chu et al., 2011). However, little is known regarding its anti-oxidative mechanism in the modulation of key cellular processes. (Chu et al., 2011) demonstrated that coffees (regular and decaffeinated) had high cellular antioxidant activity due to the availability of these compounds to the cells, which resulted in the protection of cellular components and consequently in the neutralization of cellular ROS. In present study, we observed that coffee reduced ROS production. Related to this point, the increase in expression and activity of the antioxidant enzymes superoxide dismutase (SOD), catalase and glutathione peroxidase (GPX) in the livers of rats was recently described (Vicente et al., 2014). Neutrophils also express these enzymes, which could contribute to the reduction of ROS observed in the group treated with coffee. Furthermore, it has been described that caffeic acid reduced the activity of the GTPase protein Rac1 accompanied by a decrease in NOX2 regulation (Xu et al., 2005).

During an infectious process, neutrophils induce the destruction of the infectious agent by activating NADPH oxidase NOX2 which results in the generation of ROS (Pintard et al., 2020). Thus, the phagocytic and killing activities of peritoneal neutrophils toward C. albicans were evaluated in this study.

Phagocytosis and C. albicans death by peritoneal neutrophils from diabetic animals were significantly compared to those of neutrophils from non-diabetic animals (Figure 3 and Figure 4), as described in our previous work (Souza Ferreira et al., 2016). Chronic hyperglycemia can decrease chemotactic migration of neutrophils, diapedesis, phagocytosis and bactericidal action of neutrophils, can also reduce the mobilization and phagocytic activity of polymorphonuclear leukocytes, in addition to preventing vasodilation resulting in less blood flow at the site of infection. These data demonstrate that the hyperglycemic state adversely affects the phagocytic and killing activities of peritoneal neutrophils exposed to C. albicans. It is known that the addition of ROS and proteins in the phagosome, such as lysozyme, neutral and acid proteases, phospholipases and MPO, also play an important role in the killing of pathogens. It has been shown that animals that are deficient in cathepsin $\mathrm{G}$ and elastase but produce superoxide anion normally are less resistant to infection by Staphylococcus aureus and C. albicans (Thévenod, 2008).

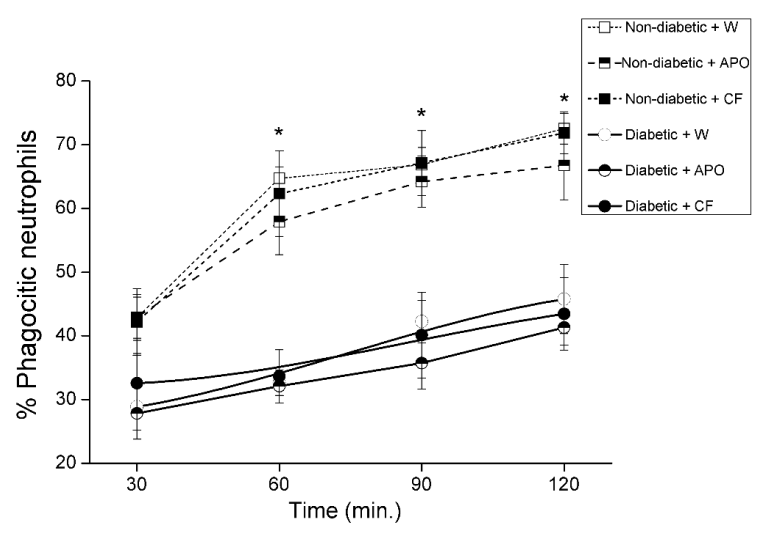

Figure 3. Evaluation of the effect of the coffee beverage and APO on the ability of neutrophils to phagocytize Candida albicans (\% phagocytic neutrophils). Neutrophils were incubated with opsonized yeast C. albicans for 30, 60,90 and $120 \mathrm{~min}$. Non-diabetics or diabetics corresponded to animals treated with: water, APO or coffee drink. The values are presented as means \pm SD of the three experiments performed in triplicate. ${ }^{*} p<0.001$ statistically significant difference compared diabetic with non-diabetic group (with the respective treatments). There was no statistical difference between treatments within each group, according to a one-way ANOVA followed by the Tukey test $(p<0.05)$. W: water; APO: apocynin; CF: coffee drink. 


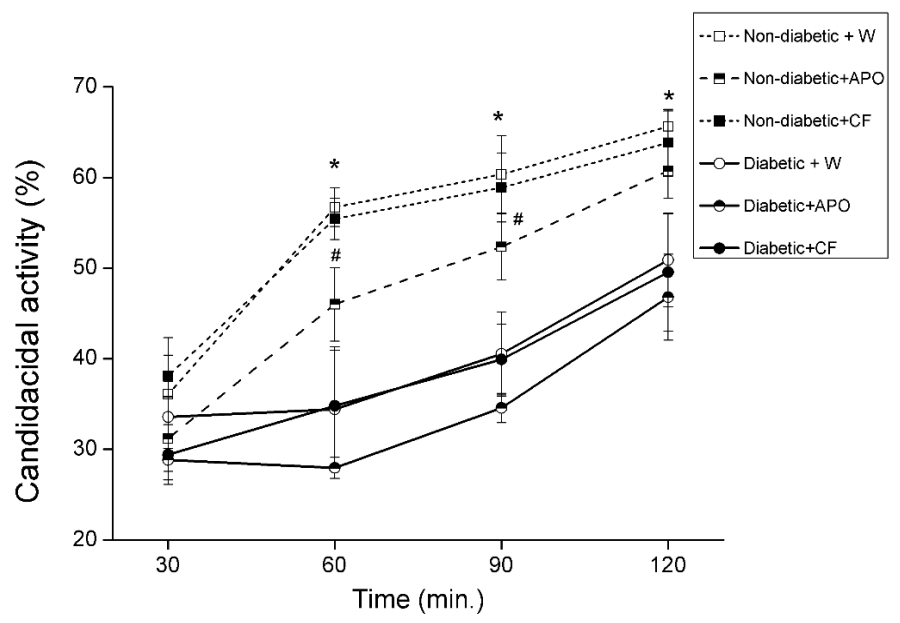

Figure 4. Evaluation of the effect of coffee beverage and of the APO on the killing of Candida albicans (candidacidal activity). Neutrophils were incubated with opsonized yeast C. albicans for 30, 60, 90 and 120 min. Non-diabetic or diabetic treated with: water, APO or coffee drink. Non-diabetics or diabetics corresponded to animals treated with: water, APO or coffee drink. ${ }^{*} p<0.001$ statistically significant difference compared diabetic with non-diabetic group (with the respective treatments). ${ }^{\#} p<0.05$ statistically significant difference compared non-diabetic + APO with non-diabetic + CF and diabetic + W. W: water, APO: apocynin, CF: coffee drink.

Despite the reduced generation of ROS by diabetic and non-diabetic groups, the coffee drink did not affect the neutrophils capacity of phagocytosis or death in our model (Figure 3 and Figure 4). Information related to the effects of coffee on the body's defense mechanism against pathogens is scarce. Experimental evidence indicates that phenolic compounds can regulate cellular processes that lead to the inflammatory response and can increase defense or not cause any type of effect (AlAmri et al., 2020; Chu et al., 2011). This controversy indicates that the response to the activity of these defenses depends on the etiology of oxidative stress, the experimental protocol, the antioxidant defense in question and the type and source of dietary antioxidant. Many of the physiological benefits of coffee have been attributed to multiple and important functions related to the ability of phenolic compounds to bind to cell receptors and membrane transporters and influence gene expression. The signaling and cell adhesion mechanisms triggered by these compounds may exert a direct action (eliminating ROS) or indirect (increasing the activity or expression of antioxidant enzymes with activation of immune defense mechanisms) (Costabile et al., 2018; Vicente et al., 2014).

In this study, apocynin was used as a standard to evaluate its action on the microbicidal ability of neutrophils and its effect was compared with the possible antioxidant activity of coffee. As observed in Figure 2B, apocynin was effective in inhibiting the production of superoxide anion and, consequently, the ROS pool. As seen in Figure 3, apocynin did not interfere with the phagocytic ability of these cells toward C. albicans. However, a small decrease in neutrophil microbicidal capacity of animals treated with apocynin occurred, at 60 and 90 minutes, most likely due to the decreased ROS produced by these cells (Figure 4). (Stolk et al., 1994) reported that apocynin did not interfere with the polymorphonuclear defense because it did not affect phagocytosis or intracellular killing of Staphylococcus aureus.

In this study, we observed that apocynin inhibited the microbicidal ability of neutrophils only in the non-diabetic group (Figure 4). As stated earlier, diabetic animals had lower MPO activity, which compromises apocynin dimer formation and its activity (Souza Ferreira et al., 2012). These data support other studies which have demonstrated the importance of MPO to the activity of apocynin (Bedard and Krause, 2007; Almeida et al., 2012). It is worth noting that coffee contains many bioactive components, including chlorogenic acid, caffeine, lignin, isoflavonoids and caffeic acid which are cited as the main compounds responsible for its antioxidative action (Akash et al., 2014). The levels of these components may be high or low, depending on the species of coffee and the type of treatment (roasting process, procedure 
for extraction and other variables), which modifies the physicochemical properties of the coffee and, consequently, the effects that were described in other studies.

\section{CONCLUSIONS}

Our data showed that intake of coffee beverage did not affect the glycemic profile of nondiabetic or diabetic animals. However, coffee reduced the generation of ROS in non-diabetic and diabetic animals and did not affect neutrophil phagocytosis or killing against $C$. albicans. Treatment with apocynin decreased the production of superoxide anion by NOX2 in neutrophils from non-diabetic and diabetic rats. In addition, the apocynin decreased the killing capacity of neutrophils from non-diabetic animals against $C$. albicans, emphasizing the importance of NOX2 system for this neutrophil activity. We suggest that coffee drinking prevents oxidative damage regardless of the pathway NOX2. Finally, it is important to note that this study showed that coffee beverage consumption does not affect the response of the organism against opportunistic pathogens such as Candida albicans.

\section{ACKNOWLEDGEMENTS}

The authors thank the "Fundação de Amparo à Pesquisa de Minas Gerais" (FAPEMIG, Minas Gerais, Brazil) and the "Coordenação de Aperfeiçoamento de Pessoal de Nível Superior" (CAPES, Brazil) for financial support.

\section{REFERENCES}

Akash MSH, Rehman K, Chen S. Effects of coffee on type 2 diabetes mellitus. Nutr. 2014;30(7-8):755-63. http://dx.doi.org/10.1016/j.nut.2013.11.020. PMid:24984989.

AlAmri OD, Albeltagy RS, Akabawy AM, Mahgoub S, Abdel-Mohsen DM, Moneim AEA, Amin HK. Investigation of antioxidant and anti-inflammatory activities as well as the renal protective potential of green coffee extract in high fat-diet/streptozotocin-induced diabetes in male albino rats. J Funct Foods. 2020;103996. http://dx.doi.org/10.1016/j.jff.2020.103996.

Anyanwu GO, lqbal J, Khan SU, Zaib S, Rauf K, Onyeneke CE, Ojo OO, Nisar-Ur-Rahman. Antidiabetic activities of chloroform fraction of Anthocleista vogelii Planch root bark in rats with diet-and alloxan-induced obesitydiabetes. J Ethnopharmacol. 2019;229:293-302. http://dx.doi.org/10.1016/j.jep.2018.10.021. PMid:30342966.

Association AD. Standards of medical care in diabetes-2016 abridged for primary care providers. Clin Diabetes. 2016;34(1):3-21. https://doi.org/10.2337/diaclin.34.1.3

Bacevic M, Rompen E, Radermecker R, Drion P, Lambert F. Practical considerations for reducing mortality rates in alloxan-induced diabetic rabbits. Heliyon. 2020;6(6):e04103. http://dx.doi.org/10.1016/j.heliyon.2020.e04103. PMid:32577551.

Bedard K, Krause K-H. The nox family of ros-generating nadph oxidases: physiology and pathophysiology. Physiol Rev. 2007;87(1):245-313. http://dx.doi.org/10.1152/physrev.00044.2005. PMid:17237347.

Butt MS, Sultan MT. Coffee and its consumption: benefits and risks. Crit Rev Food Sci Nutr. 2011;51(4):363-73. http://dx.doi.org/10.1080/10408390903586412. PMid:21432699.

Camargo MCR, Toledo MC, Farah HG. Caffeine daily intake from dietary sources in Brazil. Food Addit Contam. 1999;16(2):79-87. http://dx.doi.org/10.1080/026520399284244. PMid:10435077.

Cano-Marquina A, Tarín J, Cano A. The impact of coffee on health. Maturitas. 2013;75(1):7-21. http://dx.doi.org/10.1016/j.maturitas.2013.02.002. PMid:23465359.

Chu Y-F, Chen Y, Black RM, Brown PH, Lyle BJ, Liu RH, Ou B. Type 2 diabetes-related bioactivities of coffee: assessment of antioxidant activity, nf-kb inhibition, and stimulation of glucose uptake. Food Chem. 2011;124(3):914-20. http://dx.doi.org/10.1016/j.foodchem.2010.07.019.

Chunudom L, Thongsom M, Karim N, Rahman MA, Rana MN, Tangpong J. Tithonia diversifolia aqueous fraction plays a protective role against alloxan-induced diabetic mice via modulating GLUT2 expression. S Afr J Bot. 2020;133:118-23. http://dx.doi.org/10.1016/j.sajb.2020.07.007.

Costabile A, Sarnsamak K, Hauge-Evans AC. Coffee, type 2 diabetes and pancreatic islet function-a mini-review. J Funct Foods. 2018;45:409-16. http://dx.doi.org/10.1016/j.jff.2018.04.011. 
Almeida AC, Santos Vilela MM, Condino-Neto A, Ximenes VF. The importance of myeloperoxidase in apocyninmediated nadph oxidase inhibition. ISRN Inflamm. 2012;2012:260453. http://dx.doi.org/10.5402/2012/260453. PMid:24049643.

Melo Pereira GV, Carvalho DP No, Júnior AIM, Prado FG, Pagnoncelli MGB, Karp SG, Soccol CR. Chemical composition and health properties of coffee and coffee by-products. Adv Food Nutr Res. 2020;91:65-96. http://dx.doi.org/10.1016/bs.afnr.2019.10.002. PMid:32035601.

Souza Ferreira C, Araújo TH, Ângelo ML, Pennacchi PC, Okada SS, Araújo Paula FB, Migliorini S, Rodrigues MR. Neutrophil dysfunction induced by hyperglycemia: modulation of myeloperoxidase activity. Cell Biochem Funct. 2012;30(7):604-10. http://dx.doi.org/10.1002/cbf.2840. PMid:22610543.

Souza Ferreira C, Pennacchi PC, Araújo TH, Taniwaki NN, Araújo Paula FB, Silveira Duarte SM, Rodrigues MR. Aminoguanidine treatment increased NOX2 response in diabetic rats: improved phagocytosis and killing of Candida albicans by neutrophils. Eur J Pharmacol. 2016;772:83-91. http://dx.doi.org/10.1016/j.ejphar.2015.12.044. PMid:26724393.

Di Girolamo FG, Mazzucco S, Situlin R, Mohorko N, Jenko-Pražnikar Z, Petelin A, Tence M, Pišot R, Navarini L, Biolo G. Roasting intensity of naturally low-caffeine Laurina coffee modulates glucose metabolism and redox balance in humans. Nutr. 2016;32(9):928-36. http://dx.doi.org/10.1016/j.nut.2016.02.001. PMid:27158053.

Ding M, Fang Q-H, Cui Y-T, Shen Q-L, Liu Q, Wang P-H, Yu D-M, Li C-J. Liraglutide prevents $\beta$-cell apoptosis via inactivation of NOX2 and its related signaling pathway. J Diabetes Complications. 2019;33(4):267-77. http://dx.doi.org/10.1016/j.jdiacomp.2018.12.013. PMid:30772113.

Galijasevic S. The development of myeloperoxidase inhibitors. Bioorg Med Chem Lett. 2019;29(1):1-7. http://dx.doi.org/10.1016/j.bmcl.2018.11.031. PMid:30466896.

Inoguchi T, Battan R, Handler E, Sportsman JR, Heath W, King GL. Preferential elevation of protein kinase C isoform beta II and diacylglycerol levels in the aorta and heart of diabetic rats: differential reversibility to glycemic control by islet cell transplantation. Proc Natl Acad Sci USA. 1992;89(22):11059-63. http://dx.doi.org/10.1073/pnas.89.22.11059. PMid:1438315.

Jeszka-Skowron M, Frankowski R, Zgoła-Grześkowiak A. Comparison of methylxantines, trigonelline, nicotinic acid and nicotinamide contents in brews of green and processed arabica and robusta coffee beansinfluence of steaming, decaffeination and roasting processes on coffee beans. LWT. 2020;109344:109344. http://dx.doi.org/10.1016/j.lwt.2020.109344.

Jones OT, Hancock JT. [22] Assays of plasma membrane nadph oxidase. Methods Enzymol. 1994;233:222-9. http://dx.doi.org/10.1016/S0076-6879(94)33025-5. PMid:8015459.

Jud $\mathrm{P}$, Sourij $\mathrm{H}$. Therapeutic options to reduce advanced glycation end products in patients with diabetes mellitus: A review. Diabetes Res Clin Pract. 2019;148:54-63. http://dx.doi.org/10.1016/j.diabres.2018.11.016. PMid:30500546.

Kalschne DL, Viegas MC, De Conti AJ, Corso MP, Benassi MT. Effect of steam treatment on the profile of bioactive compounds and antioxidant activity of defective roasted coffee (Coffea canephora). LWT. 2019;99:364-70. http://dx.doi.org/10.1016/j.lwt.2018.09.080.

Kempf K, Rose B, Herder C, Haastert B, Fusbahn-Laufenburg A, Reifferscheid A, Scherbaum W, Kolb H, Martin S. The metabolic syndrome sensitizes leukocytes for glucose-induced immune gene expression. J Mol Med (Berl). 2007;85(4):389-96. http://dx.doi.org/10.1007/s00109-006-0132-7. PMid:17160670.

Kwak HS, Ji S, Jeong Y. The effect of air flow in coffee roasting for antioxidant activity and total polyphenol content. Food Control. 2017;71:210-6. http://dx.doi.org/10.1016/j.foodcont.2016.06.047.

Lee JK, Kim K, Ahn Y, Yang M, Lee JE. Habitual coffee intake, genetic polymorphisms, and type 2 diabetes. Eur J Endocrinol. 2015;172(5):595-601. http://dx.doi.org/10.1530/EJE-14-0805. PMid:25755232.

Lima AR, Pereira RGFA, Abrahão SA, Duarte SMS, Paula FBA. Duarte SMdS, Paula FBdA. Compostos bioativos do café: atividade antioxidante in vitro do café verde e torrado antes e após a descafeinação. Quim Nova. 2010;33(1):20-4. http://dx.doi.org/10.1590/S0100-40422010000100004.

Ludwig IA, Clifford MN, Lean ME, Ashihara H, Crozier A. Coffee: biochemistry and potential impact on health. Food Funct. 2014a;5(8):1695-717. http://dx.doi.org/10.1039/C4FO00042K. PMid:24671262.

Ludwig IA, Mena P, Calani L, Cid C, Del Rio D, Lean ME, Crozier A. Variations in caffeine and chlorogenic acid contents of coffees: what are we drinking? Food Funct. 2014b;5(8):1718-26. http://dx.doi.org/10.1039/C4FO00290C. PMid:25014672. 
López-Froilán R, Ramírez-Moreno E, Podio NS, Pérez-Rodríguez M, Cámara M, Baroni MV, Wunderlin DA, Sánchez-Mata M. In vitro assessment of potential intestinal absorption of some phenolic families and carboxylic acids from commercial instant coffee samples. Food Funct. 2016;7(6):2706-11. http://dx.doi.org/10.1039/C6FO00315J. PMid:27191052.

Marcucci CT, Benassi MT, Almeida MB, Nixdorf SL. Teores de trigonelina, ácido 5-cafeoilquínico, cafeína e melanoidinas em cafés solúveis comerciais brasileiros. Quim Nova. 2013;36(4):544-8. http://dx.doi.org/10.1590/S0100-40422013000400011.

Mellbye FB, Jeppesen PB, Hermansen K, Gregersen S. Cafestol, a bioactive substance in coffee, stimulates insulin secretion and increases glucose uptake in muscle cells: Studies in vitro. J Nat Prod. 2015;78(10):2447-51. http://dx.doi.org/10.1021/acs.jnatprod.5b00481. PMid:26465380.

Mirza S, Khan AA, Al-Kheraif AA, Khan SZ, Shafqat SS. Efficacy of adjunctive photodynamic therapy on the clinical periodontal, $\mathrm{HbA} 1 \mathrm{c}$ and advanced glycation end product levels among mild to moderate chronic periodontal disease patients with type 2 diabetes mellitus: A randomized controlled clinical trial. Photodiagn Photodyn Ther. 2019;28:177-82. http://dx.doi.org/10.1016/j.pdpdt.2019.08.003. PMid:31394300.

Muñoz AE, Hernández SS, Tolosa AR, Burillo SP, Olalla-Herrera M. Evaluation of differences in the antioxidant capacity and phenolic compounds of green and roasted coffee and their relationship with sensory properties. LWT. 2020;109457. http://dx.doi.org/10.1016/j.Iwt.2020.109457.

Nam SM, Lee MY, Koh JH, ParkJH, Shin JY, Shin YG, Koh SB, Lee EY, Chung CH. Effects of nadph oxidase inhibitor on diabetic nephropathy in oletf rats: the role of reducing oxidative stress in its protective property. Diabetes Res Clin Pract. 2009;83(2):176-82. http://dx.doi.org/10.1016/j.diabres.2008.10.007. PMid:19111363.

Pintard C, Khemis MB, Liu D, Dang PM-C, Hurtado-Nedelec M, El-Benna J. Apocynin prevents GM-CSF-inducedERK1/2 activation and-neutrophil survival independently of its inhibitory effect on the phagocyte nadph oxidase NOX2. Biochem Pharmacol. 2020;177:113950. http://dx.doi.org/10.1016/j.bcp.2020.113950. PMid:32251677.

Qiu J, Zhao J, Li J, Liang X, Yang Y, Zhang Z, Zhang X, Fu H, Korantzopoulos P, Liu T, Li G. NADPH oxidase inhibitor apocynin prevents atrial remodeling in alloxan-induced diabetic rabbits. Int J Cardiol. 2016;221:812-9. http://dx.doi.org/10.1016/j.jjcard.2016.07.132. PMid:27434350.

Reis CE, Dórea JG, da Costa TH. Effects of coffee consumption on glucose metabolism: A systematic review of clinical trials. J Tradit Complement Med. 2019;9(3):184-91. http://dx.doi.org/10.1016/j.jtcme.2018.01.001. PMid:31193893.

Rodrigues MR, Rodriguez D, Russo M, Campa A. Macrophage activation includes high intracellular myeloperoxidase activity. Biochem Biophys Res Commun. 2002;292(4):869-73. http://dx.doi.org/10.1006/bbrc.2002.6724. PMid:11944894.

Romualdo GR, Rocha AB, Vinken M, Cogliati B, Moreno FS, Chaves MAG, Barbisan LF. Drinking for protection? Epidemiological and experimental evidence on the beneficial effects of coffee or major coffee compounds against gastrointestinal and liver carcinogenesis. Food Res Int. 2019;123:567-89. http://dx.doi.org/10.1016/j.foodres.2019.05.029. PMid:31285007.

Shah MS, Brownlee M. Molecular and cellular mechanisms of cardiovascular disorders in diabetes. Circ Res. 2016;118(11):1808-29. http://dx.doi.org/10.1161/CIRCRESAHA.116.306923. PMid:27230643.

Shakeel M. Recent advances in understanding the role of oxidative stress in diabetic neuropathy. Diabetes Metab Syndr. 2015;9(4):373-8. http://dx.doi.org/10.1016/j.dsx.2014.04.029. PMid:25470637.

Singh H, Singh R, Kaur S, Arora R, Mannan R, Buttar HS, Arora S, Singh B. Protective role of Phyllanthus fraternus in alloxan-induced diabetes in rats. J Ayurveda Integr Med. 2020;In Press. http://dx.doi.org/10.1016/j.jaim.2019.09.008. PMid:32088092.

Souza IP, Kang HC, Nardinelli L, Borelli P. Desnutrição protéica: Efeito sobre o espraiamento, fagocitose e atividade fungicida de macrófagos peritoneais. Rev Bras Ciênc Farm. 2001;37(2):143-151. https://doi.org/10.1590/S1415-52732008000600007.

Stefanello N, Spanevello RM, Passamonti S, Porciúncula L, Bonan CD, Olabiyi AA, Teixeira da Rocha JB, Assmann CE, Morsch VM, Schetinger MRC. Coffee, caffeine, chlorogenic acid, and the purinergic system. Food Chem Toxicol. 2019;123:298-313. http://dx.doi.org/10.1016/j.fct.2018.10.005. PMid:30291944. 
Stolk J, Hiltermann T, Dijkman J, Verhoeven A. Characteristics of the inhibition of NADPH oxidase activation in neutrophils by apocynin, a methoxy-substituted catechol. Am J Respir Cell Mol Biol. 1994;11(1):95-102. http://dx.doi.org/10.1165/ajrcmb.11.1.8018341. PMid:8018341.

Szkudelski T. The mechanism of alloxan and streptozotocin action in $\beta$ cells of the rat pancreas. Physiol Res. 2001;50(6):537-46. PMid:11829314.

Thallas-Bonke V, Thorpe SR, Coughlan MT, Fukami K, Yap FY, Sourris KC, Penfold SA, Bach LA, Cooper ME, Forbes JM. Inhibition of NADPH oxidase prevents advanced glycation end product-mediated damage in diabetic nephropathy through a protein kinase C-a-dependent pathway. Diabetes. 2008;57(2):460-9. http://dx.doi.org/10.2337/db07-1119. PMid:17959934.

Thévenod F. Pathophysiology of diabetes mellitus type 2: roles of obesity, insulin resistance and $\beta$-cell dysfunction. Diabetes Cancer. 2008;19:1-18. http://dx.doi.org/10.1159/000152019.

Tomac I, Šeruga M, Labuda J. Evaluation of antioxidant activity of chlorogenic acids and coffee extracts by an electrochemical DNA-based biosensor. Food Chem. 2020;126787:126787. http://dx.doi.org/10.1016/j.foodchem.2020.126787. PMid:32387938.

Van den Worm E, Beukelman CJ, Van den Berg AJ, Kroes BH, Labadie RP, Van Dijk H. Effects of methoxylation of apocynin and analogs on the inhibition of reactive oxygen species production by stimulated human neutrophils. Eur J Pharmacol. 2001;433(2-3):225-30. http://dx.doi.org/10.1016/S0014-2999(01)01516-3. PMid:11755156.

Van Dijk AE, Olthof MR, Meeuse JC, Seebus E, Heine RJ, Van Dam RM. Acute effects of decaffeinated coffee and the major coffee components chlorogenic acid and trigonelline on glucose tolerance. Diabetes Care. 2009;32(6):1023-5. http://dx.doi.org/10.2337/dc09-0207. PMid:19324944.

Vicente SJ, Ishimoto EY, Torres EA. Coffee modulates transcription factor Nrf2 and highly increases the activity of antioxidant enzymes in rats. J Agric Food Chem. 2014;62(1):116-22. http://dx.doi.org/10.1021/jf401777m. PMid:24328189.

Wang Y, Tao J, Jiang M, Yao Y. Apocynin ameliorates diabetic retinopathy in rats: involvement of TLR4/NF-KB signaling pathway. Int Immunopharmacol. 2019;73:49-56. http://dx.doi.org/10.1016/j.intimp.2019.04.062. PMid:31078925.

Winterbourn CC, Kettle AJ. Redox reactions and microbial killing in the neutrophil phagosome. Antioxid Redox Signal. 2013;18(6):642-60. http://dx.doi.org/10.1089/ars.2012.4827. PMid:22881869.

Wu C-H, Huang H-W, Lin J-A, Huang S-M, Yen G-C. The proglycation effect of caffeic acid leads to the elevation of oxidative stress and inflammation in monocytes, macrophages and vascular endothelial cells. J Nutr Biochem. 2011;22(6):585-94. http://dx.doi.org/10.1016/j.jnutbio.2010.05.002. PMid:20951562.

Xin R, Sun X, Wang Z, Yuan W, Jiang W, Wang L, Xiang Y, Zhang H, Li X, Hou Y, Sun W, Du P. Apocynin inhibited NLRP3/XIAP signalling to alleviate renal fibrotic injury in rat diabetic nephropathy. Biomed Pharmacother. 2018;106:1325-31. http://dx.doi.org/10.1016/j.biopha.2018.07.036. PMid:30119203.

Xu J-W, Ikeda K, Kobayakawa A, Ikami T, Kayano Y, Mitani T, Yamori Y. Downregulation of Rac1 activation by caffeic acid in aortic smooth muscle cells. Life Sci. 2005;76(24):2861-72. http://dx.doi.org/10.1016/j.lfs.2004.11.015. PMid:15808886.

Yoshinari O, Takenake A, Igarashi K. Trigonelline ameliorates oxidative stress in type 2 diabetic goto-kakizaki rats. J Med Food. 2013;16(1):34-41. http://dx.doi.org/10.1089/jmf.2012.2311. PMid:23256445.

\section{Authors' contributions}

ASDS, CSF and TFOL performed the experiments, collected and analyzed the data; RGFAP, SMSD and MRR designed the study and performed the data evaluation; EBF statistical analysis; ARL assisted in the analysis of coffee; FBAP and THA performed the data evaluation; ASDS and MRR wrote the paper; SAF analysis and evaluation of data and wrote the paper.

The study was carried out at Federal University of Alfenas - UNIFAL-MG, Alfenas, Minas Gerais, Brazil. 